\title{
Peran komite sekolah dalam meningkatkan mutu pendidikan: Studi pada SMP Negeri 1 Surakarta
}

Oleh:

Effendy Irawan

Universitas Sebelas Maret

ifendy445@gmail.com

Nurhadi

Universitas Sebelas Maret

nurhadi@staff.uns.ac.id

Yuhastina

Universitas Sebelas Maret

yuhastina@staff.uns.ac.id

\begin{abstract}
Abstrak
Penelitian bertujuan untuk mendiskripsikan peran komite sekolah dalam upaya peningkatan mutu pendidikan di SMP Negeri 1 Surakarta. Metode penelitian yang digunakan adalah deskriptif kualitatif, dengan teknik pengumpulan data wawancara mendalam. Analisis data dilakukan dengan menggunakan teknik analisis data kualitatif model Miles \& Huberman. Hasil penelitian menunjukan bahwa disfungsi tugas komite sekolah sebagai penindaklanjut aspirasi masyarakat tidak mempengaruhi turunnya mutu pendidikan di SMP Negeri 1 Surakarta. Hal ini karena perangkat pendidikan SMP Negeri 1 Surakarta sebagai sebuah sistem sosial bersifat otopoietik yang dapat memperbaharui ketidakberfungsian pada salah satu atau beberapa subsistem pendidikan. Partisipasi diperluas dalam berbagai aspek baik sarana, prasarana, maupun kerajasama dengan stake holder.

Kata Kunci: komite sekolah, mutu pendidikan, sosiologi pendidikan
\end{abstract}

\begin{abstract}
This study aims to reveal the role of the school committee in efforts to improve the quality of education in Surakarta 1 Public Junior High School. The research method used is descriptive qualitative, with data collection techniques by interview. Data analysis was performed using the Milles \& Huberman analysis technique model. The conclusion of this study is the dysfunction in the school committee's duties as a followup role for community aspirations does not affect the decline in the quality of education at Surakarta 1 Public Junior High School. This is because the educational apparatus of Surakarta 1 Public Junior High School as a social system is autopoietic which can renew the malfunctioning in one or several of its subsystems. Participation is expanded in various aspects, including facilities, infrastructure, and cooperation with stakeholders.

Keywords: school committee, quality of education, sociology of education
\end{abstract}




\section{Pendahuluan}

Pengelolaan sistem pendidikan yang dilakukan secara sentralistik dan birokratis menjadi salah satu penyebab rendahnya mutu dan kualitas pendidikan. Sentralisasi yang bermuara pada standardisasi tidak dapat disamaratakan pada seluruh wilayah dengan disparitas yang tinggi. Sementara itu dikelolanya pendidikan berdasarkan hasil-hasil kesepakatan masyarakat dengan warga sekolah merupakan suatu indikasi keberhasilan dalam penyelenggaraan pendidikan (Soepono, 2012). Salah satu solusi yang ditawarkan pemerintah adalah dengan menetapkan standar nasional pendidikan. Badan Standar Nasional Pendidikan (BSNP) telah menetapkan delapan komponen standar kriteria minimal sebagai acuan mutu satuan pendidikan, yaitu (1) Standar kompetensi ulusan; (2) Standar isi; (3) Standar proses; (4) Standar pendidik dan tenaga kependidikan; (5) Standar sarana dan prasarana; (6) Standar pengelolaan; (7) Standar pembiayaan; dan (8) Standar penilaian pendidikan (Peraturan Pemerintah Republik Indonesia Nomor 13 Tahun 2015, 2015). Peneliti memilih standar proses sebagai fokus pada penelitian ini. Standar Proses menjadi acuan minimal dalam pelaksanaan proses belajar mengajar (Purwanto, 2016).

Upaya peningkatan mutu pendidikan secara umum melatarbelakangi dibentuknya komite sekolah sebagai solusinya upaya untuk memperbaiki keadaan (Aziz, 2015; Muliati \& Arifin, 2018; Mursidi, 2013; Sadewa dan Yuniningsih, 2016; Supa'at, 2012). Keberadaan komite sekolah tersebut berfungsi sebagai peningkatan mutu pelayanan pendidikan (Kementrian Pendidikan dan Kebudayaan Republik Indonesia, 2016). Dalam menjalankan fungsi sebagai peningkat mutu pendidikan, komite sekolah memiliki empat tugas konkret yang telah ditetapkan pemerintah sebagai upaya pencapaiannya, antara lain (1) memberi pertimbangan penentuan kebijakan; (2) menggalang dana; (3) mengawasi pelayanan pendidikan; dan (4) menindaklanjuti aspirasi masyarakat.

Pada prosesnya ditemukan disfungsi pada salah satu atau lebih tugas komite sekolah di beberapa satuan pendidikan. Pada salah satu satuan pendidikan di Kota Banda Aceh, peran komite sekolah yang berjalan dengan tepat hanyalah pada peran sebagai penggalang dana (Hasan, 2014). Penelitian yang dilakukan di Kabupaten Bantul, ditemukan komite sekolah yang terkendala menjalankan tugas sebagai pemberi pertimbangan karena tidak adanya wadah ruang gerak demokrasi untuk saling memberi saran (Muntadi dkk., 2016). Salah satu satuan pendidikan di Kabupaten Kebumen, disfungsi komite sekolah terjadi pada peran pendukung dan pengawas (Sadewa dan Yuniningsih, 2016). SD N Sumberporong 03, sekolah negeri 
maupun swasta di Kabupaten Lamongan, SMK di wilayah Jakarta, dan SD N seKecamatan Cakranegara, komite sekolah sebagai pengawas pelayan pendidikan, ditemukan beberapa kendala dalam keberjalanannya. Beberapa faktor tersebut antara lain ialah kesibukan profesi masing-masing anggota komite sekolah (Hanafi dan Ma'sum, 2015; Kriswanto dan Muhyadi, 2013; Maujud, 2017; Mulyono, 2014; Pratiwi dkk., 2016).

Meski demikian, secara keseluruhan tidak ditemukan melemahnya mutu pendidikan di berbagai satuan pendidikan tersebut secara langsung. Hal ini lah yang mendorong peneliti melakukan penelitian mengenai peran komite sekolah dalam peningkatan mutu pendidikan sehingga diketahui bagaimana mutu pendidikan terwujud ketika terdapat disfungsi pada salah satu atau lebih tugas komite sekolah. Pada penelitian ini, bagaimana mutu pendidikan tetap dapat terwujud meski terdapat disfungsi pada salah satu atau beberapa fungsi komite sekolah. Yang mana pada penelitian sebelumnya tidak dilakukan pembahasan pada fokus tersebut.

Tempat penelitian yang dipilih ialah SMP N 1 Surakarta. Hal tersebut karena SMP N 1 Surakarta memiliki capaian standar mutu pendidikan yang baik, dilihat dari hasil Ujian Nasional 2019 sebagai subsistem penilaian Standar Nasional Pendidikan (SNP). Keberhasilan Ujian Nasional suatu sekolah merupakan keberhasilan pula dalam pencapaian mutu pendidikan pada standar proses (Putri, 2019). Pada tahun 2019, SMP N 1 Surakarta menduduki peringkat ke-7 se-Jawa Tengah sebagai SMP terbaik dalam pencapaian hasil Ujian Nasional kategori sekolah negeri. Sedangakan dalam kategori sekolah negeri dan swasta, SMP N 1 Surakarta menduduki peringkat ke-9 pada tahun yang sama dengan total nilai rerata UN 89,95 (Harususilo, 2019b, 2019a). Selain itu, SMP N 1 Surakarta masuk dalam 503 besar peringkat nasional sebagai sekolah dengan indeks integritas tertinggi yang ditentukan berdasarkan Indeks Integritas Ujian Nasional selama enam tahun berturut-turut (Kementerian Pendidikan dan Kebudayaan, 2015).

\section{Metode Penelitian}

Metode penelitian yang digunakan adalah desktriptif kualitatif, yakni jenis penelitian yang digunakan untuk mengungkapkan fenomena yang tidak dapat dikuantifikasikan (Sugiyono, 2010). Metode ini tepat sebagai upaya pengungkapan fenomena sosial umumnya dan interaksi antar unit pada lembaga atau masyarakat pada khususnya. Tempat yang digunakan dalam penelitian ini adalah SMP Negeri 1 Surakarta, yang didasarkan atas kriteria yang peneliti buat. Peneliti mencari satuan 
pendidikan yang memiliki capaian baik pada standar mutu pendidikan. Yang mana SMP N 1 Surakarta telah menunjukan ketercapaian tersebut melalui hasil nilai Ujian Nasional dengan rerata total 89,95. Nilai tersebut menjadikan SMP N 1 Surakarta masuk pada 10 besar SMP se-Jawa Tengah dalam pencapaian nilai Ujian Nasional, baik pada kategori sekolah negeri maupun negeri dan swasta. Secara umum, seluruh SMP di kota Surakarta telah menunjukan ketercapaian delapan standar pendidikan pada angka yang cukup tinggi yakni di atas 90 persen (Purwanto, 2016). Hal tersebut adalah salah satu alasan peneliti memilih kota Surakarta sebagai sampel penelitian, yang terkhusus adalah SMP N 1 Surakarta.

Penelitian menggunakan dua sumber data, yakni sumber data primer yang berasal dari komite sekolah, guru sebagai pelaksana pendidikan di sekolahan, wakil kepala sekolah, dan pengawas dari Dinas Pendidikan Kota Surakarta. Serta sumber data sekunder yang antara lain ialah dokumen-dokumen sebagai penunjang sumber pertama. Data dicari melalui wawancara terstruktur, dimana peneliti telah mempersiapkan instrumen pertanyaan yang akan digunakan dalam tanya jawab.

Teknik yang digunakan dalam pemilihan sampel ialah teknik sampling purposive sampling ialah teknik penentuan sampel dengan pertimbangan tertentu (Sugiyono, 2010). Teknik tersebut merupakan teknik untuk mendapatkan sampel dengan memilih informan yang dipandang paling mengerti mengenai masalah penelitian, sehingga kemungkinan informan dapat menjadi pilihan sesuai dengan kriteria yang mendukung data penelitian. Kriteria yang telah dibuat peneliti adalah sebagai berikut (1) terhadap komite sekolah, tidak ada kriteria khusus; dan (2) terhadap guru, yang terlibat dalam pengupayaan keempat penjabaran standar proses pendidikan di SMP Negeri 1 Surakarta.

Penelitian ini menggunakan teknik uji validitas data dengan triangulasi yaitu sebuah teknik dengan melakukan crosscheck antar sumber pengambilan data serta membandingkan antar sumber data. Analisi data sebagai upaya memperoleh data jenuh dilakukan dengan tiga proses yang dikemukakan oleh Miles dan Huberman (Sugiyono, 2010), yakni (1) reduksi data: proses penyatuan seluruh data terperoleh, kemudian dilakukan pemilahan data-data yang dianggap pokok dan penting agar didapat tema serta pola situasi; (2) penyajian data: proses menguraikan data secara singkat dalam bentuk narasi, grafik, matrik, ataupun bagan sebagai upaya agar situasi yang terjadi pada apa yang diteliti dapat dipahami sebelum melanjutkan rencana kerja selanjutnya; dan (3) verifikasi: proses ini merupakan tahap penarikan kesimpulan dan verifikasi. 


\section{Hasil Penelitian dan Pembahasan}

Pada tahun ajaran 2019/2020 komite sekolah SMP $\quad$ N 1 Surakarta beranggotakan 7 orang, dengan struktur organisai satu orang sebagai ketua, satu orang sebagai sekretaris, satu orang sebagai bendahara, dan selebihnya adalah anggota. Masuknya anggota komite sekolah baru ialah melalui pertimbangan pihak sekolah dan anggota komite sekolah sebelumnya. Komite sekolah SMP N 1 Surakarta mengupayakan penyelenggaraan pendidikan yang bermutu sebagai orientasi utama dalam keberjalanannya. Indikasi keberhasilan yang digunakan oleh komite sekolah dalam mengupayakan hal tersebut ialah ketercapaian KKM nilai tiap mata pelajaran oleh masing-masing peserta didik. Komite sekolah selalu berkoordinasi dan mendukung kegiatan sekolah yang sifatnya wajib maupun tambahan sesuai dengan kurikulum.

Upaya yang dilakukan komite sekolah adalah memberi masukan, rekomendasi, dan usulan kepada sekolah mengenai program dan kebijakan sekolah yang meliputu kriteria fasilitas pendidikan, kebijakan pelaksanaan pendidikan, serta melakukan pengawasan terhadap kebijakan suatu program sekolah. Sebagai pedoman menjalankan perannya, komite sekolah selalu memastikan ketercapaian KKM. Perumusan capaian KKM merupakan tahap awal proses pembelajaran tiap periode (semester). Perumusan ini hanya dilakukan oleh Musyawarah Guru Mata Pelajaran (MGMP) tingkat sekolah pada tiap mata pelajaran. Semua mapel di sekolah tersebut memiliki KKM yang hampir sama, yakni 8o. Dasar pertimbangan dalam menyusun capaian KKM ialah tiga komponen penilaian (afektif, psikomotorik, dan kognitif). Kesiapan sekolah dalam menetapkan KKM dengan kisaran angka 80 tersebut karena adanya aspek yang dirasa siap, seperti intake peserta didik yang baik, serta sarana prasarana yang baik.

Koordinasi komite sekolah dengan pihak sekolahan dilakukan melalui rapat rutin tiap semester. Pembahasan pada rapat tersebut antara lain penyampaian kendala kegiatan serta kebutuhan dukungan komite sekolah kepada sekolah. Selain itu rapat juga diadakan ketika memang terjadi kendala yang harus diselesaikan bersama antara komite sekolah dan sekolahan dalam hal kegiatan belajar mengajar. Alur rapat tersebut ialah komite sekolah melakukan rapat dengan sekolah kemudian dilanjutkan dengan pengagendaan rapat komite sekolah dengan seluruh wali murid.

Dalam rangka meningkatkan kompetensi guru pengajaran, terutama dalam penerapan hasil pembelajaran oleh peserta didik atau praktik pengaplikasiannya, dilakukan workshop yang diinisiatifi oleh sekolahan dan komite sekolah sebanyak 
satu kali dalam satu tahun ketika libur semester. Komite sekolah terlibat langsung sebagai narasumber atau pemateri. Pembahasan dalam workshop merupaka hal-hal yang sifatnya selalu baru, seperti tentang model-model pembelajaran, media pembelajaran, serta penyusunan soal-soal dengan kriteria HOTS.

Pengaruh terhadap proses pembelajaran yang dirasakan guru dari workshop tersebut terbagi ke dalam hal perencanaan pembelajaran dan penilaian pembelajaran. Dalam perencanaan pembelajaran guru memperoleh beberapa wacana yang dapat menjadi referensi untuk digunakan, seperti metode pembelajaran berbasis student center, metode pembelajaran berbasis four point zero, perkembangan referensi sumber dan alat belajar yang sesuai dengan perkembagan teknologi, serta hal-hal dalam mempertimbangkan penetapan KKM.

Pada hal penilaian pembelajaran, guru memperoleh cara pandang baru dalam menilai peserta didik, sehingga guru mampu melakukan penilaian secara mendalam terhadap pembelajaran peserta didik. Namun dalam hal format penilaian, guru masih menggunakan metode yang telah ada sebelumnya. Selain melalui workshop, komite sekolah turut terlibat sebagai fasilitator alat pembelajaran dengan menawarkan penggunaan jaringan stasiun radio untuk pembelajaran jarak jauh. Komite sekolah sendiri yang mengupayakan bagaimana stasiun radio tersebut dapat digunakan oleh sekolah.

Upaya komite sekolah tersebut ditujukan terhadap tiga dari empat aspek proses pembelajaran, antara lain ialah tahap perencanaan pembelajaran, tahap pelaksanaan pembelajaran, serta tahap penilaian pembelajaran. Sementara pada tahap pengawasan pembelajaran, komite sekolah tidak melakukannya melalui perannya sebagai pemberi pertimbangan. Komite sekolah terlibat dalam pendanaan perbaikan dan pengembangan sarana prasarana yang mendukung pembelajaran dalam kelas, seperti air conditioner dan liquid crystal display. Selain itu komite sekolah turut mendukung kebutuhan dana untuk biaya pengajar jam tambahan bagi kelas tiga serta biaya pengajar ekstrakurikuler. Melalui peran penggalangan dana, komite sekolah hanya dapat berperan pada salah satu tahap yakni proses pelaksanaan pembelajaran. Ketiga cakupan standar proses yang lain tidak tersalurkan melalui peran komite sekolah sebagai penggalang dana (Renaningtiyas, 2013).

Pengawasan komite sekolah pada proses pembelajaran hanya pada ranah memastikan kebutuhan dukungan wali murid atas keberjalanan kegiatan belajar mengajar. Sedangkan dalam hal pengawalan kesesuaian praktik pembelajaran dengan regulasi pemerintah telah dilakukan oleh pengawas dari Dinas Pendidikan Kota 
Surakarta. Hal ini karena pengawas pendidikan dari Dinas Pendidikan memiliki peran formal dalam memastikan regulasi peraturan pemerintah bidang pendidikan dapat berjalan dengan baik di setiap satuan pendidikan, yang mana akan dilakukan bimbingan oleh dinas apabila terjadi kendala atau ketidaksesuaian proses pendidikan suatu satuan pendidikan dengan regulasi pemerintah.

Pengawasan proses pembelajaran komite sekolah berlangsung melalui peran komite sekolah sebagai wali murid masing-masing peserta didik. Seluruh keluhan yang ditampung oleh komite sekolah tersebut disampaikan oleh kepala sekolah maupun wakil kepala sekolah kepada guru melalui briefing yang diadakan setiap hari Senin. Beberapa keluhan yang sempat ada ialah tingginya intensitas tugas terhadap peserta didik. Komite sekolah turut melakukan pengawasan secara langsung dengan beberapa kali mengunjungi sekolahan ketika hari aktif kegiatan belajar mengajar (KBM) untuk melihat aktivitas di sekolahan seperti proses pembelajaran dan keberjalanan sarana prasarana. Sehingga pengawasan komite sekolah yang diorientasikan pada dukungan atas kebutuhan proses pembelajaran, tertuang dalam tahap pelaksanaan pembelajaran dengan keterlibatan komite sekolah mendukung keberjalanan dan pengembangan sarana prasarana belajar. Selain itu, komite sekolah terlibat mengawasi peserta didik baru (dari sekolahan lain) sebagai upaya penaungan penyesuaian peserta didik baru tersebut di SMP N 1 Surakarta sebagai sekolah barunya.

Melalui perannya sebagai pengawas, komite sekolah telah mengupayakan dukungan terhadap tahap perencanaan pembelajaran (pengelolaan peserta didik baru dan pemantauan langsung proses belajar peserta didik), serta tahap pelaksanaan pembelajaran (dalam hal sarana prasarana). Beberapa hal yang menjadi masukan orang tua terhadap sekolahan antara lain ialah keluhan akan pembelajaran peserta didik saat ini yang dirasa sulit, seperti tingginya intensitas tugas sekolah. Melalui peran ini, komite sekolah memberi pengaruh dalam proses perencanaan yang dilakukan oleh guru dalam kelas.

Mengacu pada Keputusan Menteri Pendidikan Dan Kebudayaan Republik Indonesia Nomor 241/P/2019, (Kementrian Pendidikan dan Kebudayaan, 2019), pengidentifikasian mutu standar proses pendidikan ditetapkan melalui 21 poin yang terbagi ke dalam 4 tahapan pembelajaran, yakni pada tahap perencanaan pembelajaran terdapat 4 poin, tahap pelaksanaan pembelajaran terdapat 9 poin, tahap penilaian pembelajaran terdapat 2 poin, sementara tahap pengawasan pembelajaran 
terdapat 6 poin. Di SMP N 1 Surakarta, seluruh poin pada 4 tahap dinilai baik atau kategori nilai A.

Setelah digunakannya keputusan menteri tersebut dalam memandang peran komite sekolah di SMP N 1 Surakarta, diketahui bahwa tidak semua upaya komite sekolah merupakan faktor yang berpengaruh pada peningkatan mutu pendidikan. Hanya beberapa peran dari komite sekolah yang relevan dengan kebutuhan sekolahan dalam peningkatan mutu pendidikan.

Pada tahap perencanaan pembelajaran, indikasi dibagi menjadi 4, antara lain (1) Kelengkapan komponen yang termuat dalam silabus; (2) persentase mata pelajaran yang menerapkan poin satu (1); (3) pengalokasian jam pembelajaran sesuai ketentuan; dan (4) penerapan jumlah maksimum peserta didik per rombongan belajar. Pada tahap ini, hanya satu poin yang terdapat keterlibatan komite sekolah melalui perannya sebagai pengawas pelayan pendidikan, yakni pada poin penerapan jumlah maksimum peserta didik per rombongan belajar (poin ke-4). Dimana komite sekolah turut mengawasi jumlah peserta didik per kelas ketika terdapat peserta didik baru pada pertengahan masa pembelajaran berlangsung (peserta didik pindahan dari sekolahan lain). Jumlah peserta didik dalam satu rombongan belajar berpengaruh pada keberhasilan belajar. Hal ini sesuai dengan temuan Sule dan Samuel (2016) terkait strategi pencapaian efisiensi proses belajar mengajar yang menunjukan bahwa semakin besar ukuran kelas peserta didik maka justru akan semakin rendah kinerja belajar peserta didik. Dengan ukuran kelas yang tidak besar, guru akan lebih efektif melakukan pemantauan belajar peserta didik, pemberian tugas, serta memberi perhatian lebih pada perbedaan peserta didik (Sule dan Sardauna, 2016). Keterlibatan masyarakat dalam penerimaan peserta didik baru merupakan salah satu bentuk efektif dalam peningkatan mutu pendidikan (Maujud, 2017).

Pada tahap pelaksanaan, indikasi dibagi menjadi 9 poin, antara lain (1) Persentase peserta didik yang telah menggunakan buku teks pelajaran; (2) Pengelolaan kelas secara baik oleh guru; (3) penerapan langkah pendahuluan awal pembelajaran oleh guru; (4) kesesuaian model pembelajaran; (5) kesesuaian metode pembelajaran; (6) kesesuaian media pembelajaran; (7) kesesuaian sumber belajar; (8) kesesuaian pendekatan pembelajaran; serta (9) penerapan langkah penutupan akhir pembelajaran oleh guru.

Pada tahap ini, keterlibatan komite sekolah hanya ada pada tiga poin, yakni (a) pengelolaan kelas secara baik oleh guru (poin ke-2); (b) kesesuaian model pembelajaran (poin ke-4); dan (c) kesesuaian media pembelajaran (poin ke-6). Pada 
ketiga poin tersebut komite sekolah berperan melalui tugasnya sebagai pemberi pertimbangan, penggalang dana, serta sebagai pengawas pelayan pendidikan. Peran komite sekolah sebagai pemberi pertimbangan tertuang pada pelaksanaan workshop, yang mana komite sekolah terlibat sebagai pemateri dan menyampaikan wacana referensi metode pembelajaran berbasis student center. Wacana pembelajaran berbasis student center relevan dengan kebutuhan guru dalam membangun model pembelajaran serta pengelolaan kelas secara baik. Dalam upaya peningkatan kemampuan pengelolaan kelas, diperlukan adanya pelatihan khusus (Idris dan Lestari, 2017; Renaningtiyas, 2013; Stepanili, dkk., 2019). Dalam temuan lain juga menjelaskan bahwa peran komite sekolah sebagai narasumber yang dalam kaitan ini adalah narasumber workshop dan keikutsertaannya dalam pengembangan perumusan program sekolah, memang diperlukan dalam peningkatan mutu pendidikan (Aziz, 2015).

Keikutsertaan komite sekolah pada perbaikan LCD merupakan penerapan tugas sebagai penggalang dana dan pengawas pelayan pendidikan. Penggalangan dana merupakan salah satu bentuk pelibatan komite ekolah yang efektif terhadap peningkatan mutu pendidikan (Septiana dkk., 2018). Keberadaan sarana prasarana belajar memiliki pengaruh terhadap keadaan mutu pendidikan suatu sekolah (Idris \& Lestari, 2017; Salahuddin et al., 2018). Hal ini ditegaskan lebih lagi dengan temuan yang dilakukan oleh Andika Saputra Siregar yang menyatakan bahwa dukungan komite dalam hal finansial serta sebagai peran pendukung yang dalam hal ini kaitannya adalah sebagai penggalang dana, sesuai dengan upaya peningkatan mutu pendidikan (Siregar, 2014).

Pada tahap penilaian, indikasi dibagi menjadi dua poin, yakni (1) persentase guru yang menggunakan pendekatan penilaian otentik; serta (2) persentase guru yang memanfaatkan hasil penilaian otentik. Tidak ada peran komite sekolah yang berdampak pada salah satu poin tersebut. Meski pada pelaksanaan tugas pemberi pertimbangan terdapat upaya komite sekolah dalam tahap penilaian pembelajaran. Namun upaya tesebut bukan merupakan faktor yang berpengaruh pada proses penilaian di SMP N 1 Surakarta, karena guru tetap menggunakan format cara penilaian lama.

Pada tahap pengawasan proses pembelajaran, terdapat 6 poin sebagai indikator, antara lain (1) objektifitas dan transparansi pengawasan proses pembelajaran oleh kepala sekolah; (2) persentase guru tersupervisi oleh kepala sekolah; (3) upaya pemantauan proses pembelajaran oleh kepala sekolah; (4) upaya penindaklanjutan 
hasil supervisi proses pembelajaran; (5) pengerjaan laporan pengawasan yang disusun oleh kepala sekolah; serta (6) persentase hasil pengawasan yang ditindaklanjuti. Seperti pada tahap penilaian pembelajaran, pada tahap pengawasan tidak ada pengaruh atas keikutsertaan peran komite sekolah di dalamnya sama sekali. Hal ini karena memang kegiatan supervisi hanya dapat dilakukan oleh pihak yang memiliki kompetensi, yakni kepala sekolah pada tiap satuan pendidikan. Secara umum, supervisi memang dilakukan oleh kepala sekolah karena memang hal ini merupakan bantuan yang dilakukan oleh para pemimpin sekolah kepada perkembangan kinerja guru dalam mengupayakan keberhasilan kegiatan belajar mengajar (Purwanto, 2008).

Grafik 1. Peran Komite Sekolah berdasaran Keputusan Menteri Pendidikan dan Kebudayaan Republik Indonesia Nomor 241/P/2019.

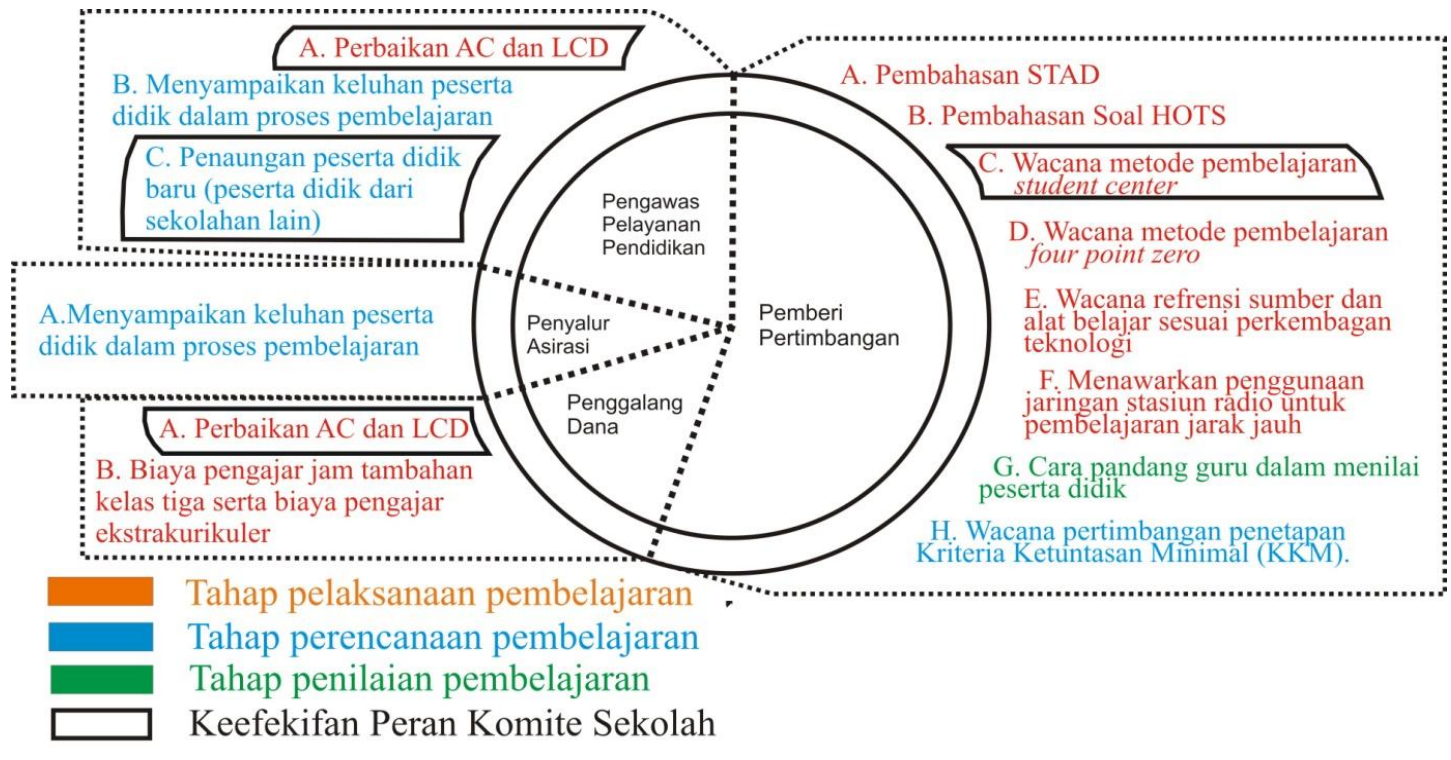

Peran komite sekolah terhadap peningkatan mutu pendidikan SMP N 1 Surakarta hanya tersalurkan pada tahap (1) perencanaan; dan (2) pelaksanaan pembelajaran. pada kedua tahap tersebut, komite sekolah terlibat melalui perannya sebagai (1) pemberi pertimbangan; (2) peggalang dana; dan (3) pengawas pendidikan. Dua tahapan pembelajaran yang lain tidak menerima pengaruh peran komite sekolah, yakni pada tahap penilaian pembelajaran serta pengawasan pembelajaran. Yang mana secara haluan kerja, komite sekolah telah melaksanakan keempat peran yang harus dijalankan terhadap seluruh tahapan pembelajaran yang ada. Ketidakberdampakan peran komite sekolah pada suatu tahapan disebabkan oleh ketidaktepatan antara 
kebutuhan upaya peningkatan mutu pendidikan dengan apa yang diberikan komite sekolah melalui suatu perannya.

Meski terjadi disfungsi dalam keberjalanan peran komite sekolah, capaian mutu standar proses pendidikan di SMP N 1 Surakarta tergolong baik. Hal tersebut karena ketidakberdampaknya fungsi komite sekolah terhadap tahap pembelajaran penilaian dan pengawasan, terupayakan oleh faktor lain di luar komite sekolah itu sendiri. Sehingga sesuai dengan beberapa temuan penelitian sebelumnya yang menyatakan bahwa adanya disfungsi pada peran komite sekolah tidak menyebabkan turunnya mutu pendidikan tiap satuan pendidikan.

Teori sistem yang digagas oleh Niklas Luhmann (Baraldi dan Corsi, 2017) menyatakan bahwa suatu sistem tidak akan hancur ketika terjadi ketidakberfungsian pada salah satu subsistem di dalamnya, karena sistem sosial dengan sendirinya akan menggantikannya dengan fungsi-fungsi baru. Hal ini lah yang disebut oleh Niklas luhmann bahwa sistem sosial bersifat otopoietik. Otopoietik merupakan suatu konsep yang diadaptasi oleh Niklas Luhmann dari disiplin ilmu biologi. Dimana suatu sistem kehidupan memiliki kemampuan untuk membenahi dirinya sendiri dengan cara mereproduksi sel yang mati pada dirinya (Baraldi \& Corsi, 2017). Fokus dari teori ini ialah pada analisis bagaimana suatu masyarakat atau masyarakat di dalam masyarakat membentuk dirinya, sehingga dengan teori ini penulis berusaha menggambarkan perangkat pendidikan SMP N 1 Surakarta sebagai suatu sistem sosial bagian dari masyarakat serta bagaimana proses pembentukan dirinya.

Disebut suatu sistem sosial apabila terdapat perbedaan dengan lingkungannya. Sisi perbedaan dari sistem sosial dengan lingkungan adalah sistem sosial melakukan operasi diri. Yang mana lingkungan tidak dapat secara langsung memberi pengaruh terhadap sistem sosial pada proses tersebut. Lingkungan hanya memberikan sebuah gangguan kepada sistem sosial, hingga kemudian sistem sosial merespon sendiri sebagai sebuah iritasi yang hari segera didaur ulang. Proses daur ulang inilah yang dilakukan oleh sistem sosial secara tertutup tanpa pengaruh dari lingkunagn. Sehingga titik pemisah antara keduanya adalah pada proses yang tertutup tersebut (Baraldi dan Corsi, 2017). Otopoietik pada suatu sistem sosial memiliki empat karakteristik, antara lain (1) Menghasilkan unsur-unsur dasar yang membentuk sistem itu; (2) Mengorganisasi diri; (3) Mengacu pada diri sendiri; dan (4) Suatu sistem yang tertutup (Ritzer, 2012).

Sekolah sebagai sistem peningkat mutu pendidikan terbentuk dengan mendasarkan diri pada acuan akreditasi mutu pendidikan, yang kemudian berdiri 
diatasnya beberapa subsistem-subsistem dari sistem peningkat mutu pendidikan tersebut. komite sekolah merupakan salah satu dari subsistem tersebut. Pengolahan akreditasi mutu tersebut dilakukan secara tertutup oleh perangkat sekolah sebagai suatu sistem sosial. Perencanaan-perencanaan yang disusun oleh komite dan kepala sekolah tanpa keterlibatan pihak luar sekolah yang dalam hal ini Dinas Pendidikan Kota Surakarta merupakan bentuk proses operasinal secara terutup sebagai sistem sosial (Baraldi dan Corsi, 2017). Sistem peningkat mutu pendidikan mengorganisasi diri dengan dua cara, yakni dengan mengorganisasi perbatasan-perbatasannya sendiri, serta mengorganisasi struktur-struktur internalnya. Pada kaitannya dengan komite sekolah, ia adalah subsistem yang muncul sebagai cara sistem sosial mengorganisasi struktur-struktur internalnya.

Pada tahap pengorganisasian batasan-batasannya, perangkat sekolah sebagai sistem peningkat mutu pendidikan bergerak pada hal-hal yang mengacu pada akreditasi peningkatan mutu pendidikan saja. Kemudian lanjutan dari tahap tersebut ialah pengorganisasian struktur-struktur internal. Pada tahap kedua ini, terdapat beberapa kebutuhan-kebutuhan baru yang mengharuskan adanya struktur baru dalam pencapaiannya. Kebutuhan-kebutuhan tersebut antara lain seperti keterlibatan masyarakat yang lebih lagi dalam meningkatkan mutu pendidikan, sehingga munculah komite sekolah sebagai struktur internal tersebut. Pedoman akreditasi sekolah/madrasah digunakan dalam pengacuan sistem kepada diri sendiri oleh komite sekolah selaku subsistem peningkat mutu pendidikan. Komite sekolah bergerak berdasarkan pedoman akreditasi tersebut. Pada titik inilah bentuk gangguan dari lingkungan diterima oleh perangkat sebagai sistem sosial (Baraldi dan Corsi, 2017).

Komite sekolah sebagai salah satu subsistem peningkat mutu pendidikan, bersifat tertutup dari lingkungan luar (segala sesuatu di luar sistem). Komite sekolah tidak menerima pengaruh langsung dari lingkungan, dan sebagai gantinya, komite sekolah akan melakukan interaksi pada suatu bentuk representasi lingkungannya. Dalam hal ini, segala kebijakan dari pemerintah dalam hal peningkatan mutu pendidikan merupakan bentuk representasi tersebut, seperti Pedoman Akreditasi Sekolah/Madrasah, Undang-undang tentang komite sekolah, serta Undang-undang tentang peningkatan mutu pendidikan, yang mana hal-hal tersebut dapat dikatakan sebagai bentuk representasi dari lingkungan karena dapat dibaca melalui sudut pandang yang sama yakni upaya peningkatan mutu pendidikan. 


\section{Simpulan}

Terdapat disfungsi peran komite sekolah dalam upaya peningkatan mutu pendidikan di SMP N 1 Surakarta. Disfungsi tersebut terjadi pada peran sebagai penyalur aspirasi masyarakat. Terjadinya disfungsi pada komite sekolah tidak menyebabkan runtuhnya sistem sosial yang dalam hal ini perangkat sekolah sebagai sistem peningkat mutu pendidikan. Niklas Luhmann menjelaskan bagaimana cara kerja masyarakat sebagai sistem otopoietik, dengan cara struktur masyarakat tersebut menciptakan unsur-unsur masyarakat. Yang mana unsur-unsur tersebut kemudian menciptakan struktur itu.

Peran komite sekolah yang mengalami disfungsi dapat terpulihkan karena komite sekolah merupakan bagian dari sebuah "sistem sosial" memiliki kemampuan untuk mereproduksi kerusakan sel (secara otopoietik) di dalamnya. Pada hal ini, komite sekolah dan beberapa perangkat sekolah lain seperti kepala sekolah dan tenaga kependidikan, melakukan interaksi secara aktif. Beberapa ketidakberfungsian peran komite sekolah pada salah satu atau beberapa hal telah mampu diupayakan oleh pihak lain, seperti oleh kepala sekolah pada tahap penilaian pembelajaran.

\section{Referensi}

Aziz, A. Z. (2015). Manajemen berbasis sekolah: alternatif peningkatan mutu pendidikan madrasah. Jurnal EL-Tarbawi, 7(1), 70-92.

Baraldi, C. \& Corsi, G. (2017). Niklas luhman: Education as a social system. Springer.

Hanafi, I., \& Ma'sum, M. (2015). Analisis implementasi kebijakan pendidikan pendidikan: Peran komite sekolah pada sekolah menengah kejuruan. Jurnal Cakrawala Pendidikan, 34(1), 58-66.

Harususilo, Y. E. (2019a). 10 SMP negeri terbaik Jawa Tengah dalam ujian nasional 2019. Kompas.Com. kompas.com/edukasi/read/2019/06/04/07300081/10smp-negeri-terbaik-jawa-tengah-dalam-ujian-nasional-2019

Harususilo, Y. E. (2019b). 10 SMP swasta dan negeri tertinggi raihan nilai UN 2019 Jawa Tengah. Kompas.Com. kompas.com/makassar/read/2019/06/04/09300081/10-smp-swasta-dannegeri-tertinggi-raihan-nilai-un-2019-jawa-tengah

Hasan, H. (2014). Fungsi komite sekolah dalam perkembangan dan implementasi program sekolah di SD Negeri 19 Kota Banda Aceh. Jurnal Pesona Dasar, 2(3), $1-12$.

Idris, R. \& Lestari, E. (2017). Pengaruh pengorganisasian terhadap peningkatan mutu pendidikan di SD Inpres Bangkala II Kota Makassar. LENTERA PENDIDIKAN, 2O(1), 18-30.

Kriswanto, M. \& Muhyadi. (2013). Implementasi peran komite sekolah di SD Negeri 
Sumberporong 03 Kecamatan Lawang, Kabupaten Malang. Jurnal Akutabilitas Manajemen Pendidikan, 1 (1), 66-79.

Maujud, F. (2017). Peran partisipasi masyarakat dalam meningkatkan mutu pendidikan madrasah (studi kasus di Madrasah Ibtidaiyah Islahul Muta'allim Pagutan Kota Mataram). Jurnal Studi Keislaman dan Ilmu Pendidikan, 5(2), 92-121.

Peraturan Menteri Pendidikan dan Kebudayaan Republik Indonesia Nomor 75 Tahun 2016, 751 (2016).

Keputusan Menteri Pendidikan dan Kebudayaan Republik Indonesia Nomor 241/P/2019, 2416 (2019).

Muliati, \& Arifin, Z. (2018). Peran komite sekolah dalam meningkatkan mutu sekolah di SMA Negeri Makassar. Jurnal Sosialisasi Pendidikan Sosiologi, 5(2), 77-80.

Mulyono, W. D. (2014). Peran komite sekolah dalam penyelenggaraan pendidikan SMK di Kabupaten Lamongan, Jawa Timur. Jurnal Pendidikan Vokasi, 4(3), 391-404.

Muntadi, A., Zubaidah, E., \& Sumardi. (2016). Peran komite sekolah dalam peningkatan mutu pembelajaran di sekolah dasar. Jurnal Cakrawala Pendidikan, 35(3), 312-321.

Mursidi, A. (2013). Pengelolaan komite sekolah dalam meningkatkan mutu pendidikan di SD Islam Al Azhar 29 Semarang. Jurnal Manajemen Pendidikan, 2(1), 20-32.

Peraturan Pemerintah Republik Indonesia Nomor 13 Tahun 2015, 13 (2015).

Purwanto. (2016). Keefektifan sekolah dilihat dari delapan standart nasional pendidikan di wilayah eks Karesidenan Surakarta. Jurnal Penelitian Kebijakan Pendidikan, 2(2), 199-224.

Purwanto. (2008). Administrasi dan supervisi pendidikan. Bandung: PT Remaja Rosdakarya.

Putri, A., S. (2019). Sejarah ujian nasional dan dampak penghapusannya. Kompas.Com. kompas.com/skola/read/2019/12/13/100000369/sejarah-ujiannasional-dan-dampak-penghapusannya?page $=$ all

Renaningtiyas, E. (2013). Analisis pelaksanaan kebijakan manajemen berbasis sekolah dalam peningkatan mutu pendidikan di SMPN 1 Madiun. Jurnal Kebijakan dan Pengembangan Pendidikan, 1(1), 14-17.

Siregar, A. S. (2014). Efektivitas komite sekolah dalam meningkatkan mutu pendidikan di SMP Negeri 17 Pekanbaru. Jom FISIP, 1(2), 1-15.

Soepono, B. (2012). Peran komite sekolah dalam pengembangan pendidikan pengaruhnya terhadap kinerja sekolah dasar. SEKOLAH DASAR: Kajian Teori Dan Praktik Pendidikan, 21(2), 107-117.

Sugiyono. (2010). Metode penelitian kuantitatif, kualitatif, dan R\&D. Penerbit Alfabeta. 